\title{
Young university students have insufficient knowledge about preventive measures against Toxoplasma gondii infection in a region of Southern Brazil
}

\author{
Jovens universitários têm conhecimento insuficiente sobre as medidas preventivas contra infecção \\ por Toxoplasma gondii em região do Sul do Brasil
}

Jóvenes universitarios tienen un conocimiento insuficiente sobre las medidas preventivas contra

infección por Toxoplasma gondii en una región del sur de Brasil

Received: 09/03/2021 | Reviewed: 09/17/2021 | Accept: 09/23/2021| Published: 09/25/2021

Priscilla de Laet Sant'Ana ORCID: https://orcid.org/0000-0001-6462-9631

State University of Maringá, Brazil

E-mail: plaetsantana@gmail.com

Fernanda Ferreira Evangelista

ORCID: https://orcid.org/0000-0001-9576-3075

State University of Maringá, Brazil

E-mail: fer.evangelista@hotmail.com

Cibelle Marques Lima

ORCID: https://orcid.org/0000-0002-3495-0413

State University of Maringá, Brazil

E-mail: cibelle0801@gmail.com

Thaiane da Silva Candido

ORCID: https://orcid.org/0000-0001-5533-0793

State University of Maringá, Brazil

E-mail: thaianecandido@hotmail.com

Guilherme Galerani Mossini

ORCID: https://orcid.org/0000-0002-2139-653X

State University of Maringá, Brazil

E-mail: guilhermemossini@gmail.com

Leonardo Grande de Almeida

ORCID: https://orcid.org/0000-0002-8599-6235

State University of Maringá, Brazil

E-mail: leogalmeida95@gmail.com

Angélica Sayuri Sakata

ORCID: https://orcid.org/0000-0003-0506-0718

State University of Maringá, Brazil

E-mail: angelicasayurisakata@hotmail.com

Henrique Pereira dos Santos

ORCID: https://orcid.org/0000-0002-9496-9765

State University of Maringá, Brazil

E-mail: henr77@gmail.com

Beatriz Hiromi Ishikawa

ORCID: https://orcid.org/0000-0002-0454-8554

State University of Maringá, Brazil

E-mail: biaa.ishikawa@gmail.com

Lucas dos Santos de Souza

ORCID: https://orcid.org/0000-0003-0009-1451

State University of Maringá, Brazil

E-mail: lucas.stos.sza@gmail.com

Keller Karla de Lima

ORCID: https://orcid.org/0000-0002-5832-5524

State University of Maringá, Brazil

E-mail: kellerkarlalima@gmail.com

Francini Martini Mantelo

ORCID: https://orcid.org/0000-0002-4906-0691

State University of Maringá, Brazil

E-mail: francinimartini@gmail.com

Emerson Barili

ORCID: https://orcid.org/0000-0001-8210-6746 State University of Maringá, Brazil

E-mail: ebarili2@gmail.com 
Ana Gabriela Gomes Ferrari Strang

ORCID: https://orcid.org/0000-0001-7884-552X State University of Maringá, Brazil E-mail: agferraristrang@gmail.com

Ana Lúcia Falavigna-Guilherme

ORCID: https://orcid.org/0000-0001-7361-5223

State University of Maringá, Brazil

E-mail: alfalavignauem@gmail.com

*The first (Laet Sant-Ana, P) and second (Evangelista, F.F) authors equally contributed

\begin{abstract}
A representative cross-sectional study was conducted to assess the knowledge about toxoplasmosis prevention, transmission routes, clinical features, and who can be infected among students from seven teaching areas of the State University of Maringá, Southern Brazil, using a self-administrated questionnaire. A total of 600 students participated in the study, 86 students did not answer or did not know about toxoplasmosis (14.3\%), the other 514 (86.2\%) had some information about toxoplasmosis and answered the questionnaires and most of them are unaware of the routes of transmission and prevention of this zoonosis. Less than $50 \%$ considered correct the options "do not feed cats with raw meat" (39.9\%), "eat only well-cooked meats" (40.1\%), and "ingest only filtered or boiled water" (42.6\%). Also, misconceptions about prevention were identified when statements such as "doing fecal exams regularly" were considered correct by $20.0 \%$ of participants. Students' average of correct answers in the health and biological areas was statistically higher than in other areas. The agricultural sciences area had the worst performance. In conclusion, there is a critical need for effective educational programs to increase the population's awareness of toxoplasmosis since correct preventive practices are critical to control and reduce one disease's infection without definitive treatment.
\end{abstract} Keywords: Toxoplasma gondii; Foodborne diseases; Prevention; Health education.

\title{
Resumo
}

Foi realizado um estudo transversal representativo para avaliar o conhecimento sobre prevenção da toxoplasmose, vias de transmissão, características clínicas e quem pode ser infectado entre alunos de sete áreas de ensino da Universidade Estadual de Maringá, Sul do Brasil, por meio de questionário autoaplicável. Participaram do estudo 600 alunos, 86 alunos não responderam ou não sabiam sobre a toxoplasmose $(14,3 \%)$, os demais 514 (86,2\%) possuíam alguma informação sobre toxoplasmose e responderam aos questionários e a maioria desconhece o vias de transmissão e prevenção desta zoonose. Menos de 50\% consideraram corretas as opções "não alimentar gatos com carne crua" (39,9\%), "comer apenas carnes bem cozidas" (40,1\%) e "ingerir apenas água filtrada ou fervida" $(42,6 \%)$. Além disso, foram identificados equívocos sobre prevenção quando afirmações como "fazer exame de fezes regularmente" foram consideradas corretas por 20,0\% dos participantes. A média de acertos dos alunos nas áreas da saúde e biológica foi estatisticamente maior do que nas outras áreas. A área de ciências agrícolas teve o pior desempenho. Em conclusão, há uma necessidade crítica de programas educacionais eficazes para aumentar a conscientização da população sobre a toxoplasmose, uma vez que as práticas preventivas corretas são fundamentais para controlar e reduzir a infecção de uma doença sem tratamento definitivo.

Palavras-chave: Toxoplasma gondii; Doenças transmitidas por alimentos; Prevenção; Educação em saúde.

\section{Resumen}

Se realizó un estudio representativo de corte transversal para evaluar el conocimiento sobre prevención de toxoplasmosis, vías de transmisión, características clínicas y quiénes pueden infectarse entre estudiantes de siete áreas docentes de la Universidad Estatal de Maringá, Sur de Brasil, mediante un cuestionario autoadministrado. Un total de 600 estudiantes participaron del estudio, 86 estudiantes no respondieron o no sabían sobre la toxoplasmosis (14,3\%), los otros $514(86,2 \%)$ tenían alguna información sobre la toxoplasmosis y respondieron los cuestionarios y la mayoría desconoce las vías de transmisión y prevención de esta zoonosis. Menos del 50\% consideró correctas las opciones "no alimentar a los gatos con carne cruda" (39,9\%), "comer sólo carnes bien cocidas" $(40,1 \%)$ e "ingerir sólo agua filtrada o hervida" (42,6\%). Además, se identificaron conceptos erróneos sobre la prevención cuando el $20 \%$ de los participantes consideró correctas declaraciones como "hacer exámenes fecales con regularidad". El promedio de respuestas correctas de los estudiantes en las áreas de salud y biología fue estadísticamente más alto que en otras áreas. El área de ciencias agrícolas tuvo el peor desempeño. En conclusión, existe una necesidad crítica de programas educativos efectivos para aumentar la conciencia de la población sobre la toxoplasmosis, ya que las prácticas preventivas correctas son fundamentales para controlar y reducir la infección de una enfermedad sin un tratamiento definitivo.

Palabras clave: Toxoplasma gondii; Enfermedades Transmitidas por los alimentos; Prevención; Educación en salud. 


\section{Introduction}

Toxoplasmosis is a worldwide foodborne zoonotic disease caused by a protozoan, Toxoplasma gondii, that infects approximately one-third of the human world population (Dubey, 2016; Peyron et al., 2019). It is an obligate intracellular parasite capable of infecting homeothermic animals, but experimental infection in fish has already been demonstrated (Sanders et al., 2015; Yang et al., 2020; Yoshida et al., 2020). T. gondii has a complex life cycle and the felines are definitive hosts (Dubey, 2016; Peyron et al., 2019).

Humans, intermediate hosts, can get infected by ingesting raw vegetables and water contaminated by $T$. gondii oocysts (sporozoites) or consuming raw or undercooked meat containing T. gondii cysts (bradyzoites) (Dubey, 2016; RobertGangneux et al., 2012). Mother (acute phase of toxoplasmosis) to child transmission is also possible by tachyzoites passage through the placenta (J. P. Dubey, 2016; Peyron et al., 2019). T. gondii persists lifelong in the affected host organism (chronic phase) since it has no definitive treatment. This infection is usually asymptomatic and evolves into the latent (chronic) form, characterized by the formation of cysts containing bradyzoites (slow replicating form), mainly in nervous and muscle tissue (Fallahi et al., 2018; Waldman et al., 2020). It can be particularly severe when acquired during pregnancy because of the risk of congenital transmission, causing several damages to the fetus as mental retardation, brain calcification, hydrocephalus, and chorioretinitis (Maldonado et al., 2011; Peyron et al., 2019). In immunocompromised patients (Human Immunodeficiency Virus - HIV - infected individuals with $<200$ CD4+ cells/mL, use of immunosuppressive therapy or with congenital or acquired immunity diseases), reactivation of latent infection can occur with the conversion of bradyzoites into tachyzoites. That could cause systemic manifestations, especially severe in central nervous system (encephalitis, meningitis, brain abscess) with significant morbidity and $100 \%$ mortality if left untreated (Montoya \& Liesenfeld, 2004). In Central and South America, there are abundant non-archetypal T. gondii genotypes, with significant genetic variability (Bertranpetit et al., 2017; Pena et al., 2018). This genotypic diversity has been associated with different virulence patterns (Hamilton et al., 2019). It may explain the higher prevalence of severe ocular toxoplasmosis (chorioretinitis and uveitis), which are also frequent in individuals who became infected in the post-gestational period, as infant, adolescence or adult age, in countries like Brazil, Argentina and Colombia, (de-la-Torre et al., 2009; Khan, 2006; Rudzinski et al., 2016, 2019).

Brazil is considered a country with high prevalence of toxoplasmosis and a hotspot for outbreaks (Dubey, 2021). In southern Brazil, in 2002, one of the most massive global outbreaks of toxoplasmosis occurred, affecting over 400 patients (Dubey et al., 2021; Sanders et al., 2017; Silveira et al., 2015). Thirteen years later, five cases of congenital toxoplasmosis in this cohort were analyzed, among which, two were behind in school grades and four had ocular complaints and reported learning difficulties, requiring psychological and pedagogical assistance (Sanders et al., 2017). In 2018, an outbreak considered the largest ever described in the world also occurred in southern Brazil, with more than 800 cases confirmed, including several cases of retinochoroiditis, congenital cases with fetal death and abortion (Arquilla et al., 2019; Dal Ponte et al., 2019). New T. gondii genotypes were isolated during this outbreak exhibiting high virulence, and the intensity of the symptoms presented warrants attention (Minuzzi et al., 2020; Pinto-Ferreira et al., 2020).

The treatment of toxoplasmosis remains a significant challenge for science because available drug schemes are not fully effective, not being able to reach bradyzoites inside tissue cysts, and present severe side effects, including bone marrow suppression, hematologic toxicity, and life-threatening allergic reactions (Dunay et al., 2018; Montoya \& Liesenfeld, 2004; Peyron et al., 2019). Therefore, the most reliable strategies for prevention, diagnosis, and early treatment of infection, as in pregnant women, include systematic education and detection by laboratory tests. Several studies have sought to measure knowledge about prevention and transmission of toxoplasmosis among health professionals and pregnant women showing an incomplete understanding of these aspects, reinforcing the need for continuing health education to prevent infection(Branco et 
al., 2012; Contiero-Toninato et al., 2014; Higa et al., 2010; Martini et al., 2020; Moura et al., 2017; Senosy, 2020). These zoonosis prevention practices should be disseminated and encouraged, especially among susceptible pregnant women and young people, considering the expressive prevalence and severity of ocular lesions (Gilbert et al., 2008), even in postnatal infection, and high diversity of genotypes, especially in South America (Ait Hamou \& Laboudi, 2021; Pena et al., 2018; Velázquez-Hernández et al., 2019). Health education programs are proven to decrease the disease's prevalence and improve the knowledge about it and prevention practices (Bertran-Luengo et al., 2021; Binquet et al., 2019; Jones et al., 2014; Smith et al., 2021).

Due to the high prevalence and severity of toxoplasmosis and the absence of more effective treatments, there is a need to improve health education strategies for this zoonosis. Our toxoplasmosis research group belongs to a public university with activity in gestational and congenital toxoplasmosis diagnosis and follow-up, covering 30 municipalities with a estimate population of 750,000 inhabitants. Since 2003 educational and guidance work has been carried out on toxoplasmosis prevention among students in school grade and health professionals in diverse public and private services (Branco et al., 2012; Contiero-Toninato et al., 2014; Evangelista et al., 2017; Higa et al., 2010; Marchioro et al., 2015; A. P. Sanders et al., 2017). Also, digital platforms were developed to disseminate knowledge about toxoplasmosis, such as websites, social media pages and mobile applications (Evangelista et al, 2018). Considering all the work developed during the last two decades and that this university is a reference in learning quality in our region, this study aimed to access toxoplasmosis-related knowledge among the young university students of a public university in southern Brazil.

\section{Methodology}

A representative cross-sectional study was conducted with university students from the State University of Maringá (UEM), Paraná State, Southern Brazil, to assess the knowledge about some essential aspects of toxoplasmosis as transmission routes, disease manifestations, and preventive practices. This public institution is the second most important university in Paraná State and one of the most important in southern Brazil, with about 18,000 undergraduate students distributed in seven campi. The study was carried out with students from all grades in the main campus located in the city of Maringá, which has approximately 8,000 undergraduate students, in 32 courses distributed in seven different teaching centers: Health Sciences (with six courses); Technological Sciences (eight courses); Humanities, Letters, and Arts (six courses); Social Sciences (four courses); Exact Sciences (two courses); Biological Sciences (two courses) and Agrarian Sciences (two courses). The minimal sample was estimated in 5\% of the 8,000 students, proportionally distributed by area. Students who already had the discipline of parasitology were excluded. The seven teaching centers were brought together into four groups. Group 1, health and biological sciences. Group 2, exact and technological science. Group 3, humanities and social sciences. Group 4 agricultural sciences.

This university has a school hospital located in Maringá, a city of 423,666 inhabitants, which maintains a referral clinic to treat gestational and congenital toxoplasmosis in the region. The human development index (HDI) is 0.808 , according to data from the Brazilian Institute of Geography, 2019.

After signing the informed consent form, participants filled out a standard questionnaire that was designed by the researchers. This questionnaire was self-completed without the participation of the researchers, and the identification data was kept anonymous. The first question (Do you know what toxoplasmosis is?) was a defining factor for counting other responses. Another 23 closed questions, in which the respondent could indicate "yes" or "no", were designed to assess knowledge on the subject. These 23 questions were grouped into 4 categories: 7 statements about the clinical features of toxoplasmosis in humans; 9 about how to prevent toxoplasmosis; 4 about how humans become infected and 3 statements of who can be infected. 
Academic students trained teams in the nursing and medical courses were responsible to apply the questionnaires. After completing the questionnaire, participants received a printed material with information about toxoplasmosis and prevention practices. Also, they were informed about digital media tools of toxoplasmosis developed by the toxoplasmosis study group at this university bringing additional information about the disease as blogs, web pages, and mobile apps (Figure 1).

To calculate the sample size, we used a 5\% significance level, with an 8,000 population size (undergraduate students at day time period) and a confidence coefficient of 95\%. With $\mathrm{N}=8,000$, a minimum sample size of 367 students was obtained. To statistical analyses, correct answers received a score of "1" and an incorrect score of "0". A quasibinomial linear model was adjusted using the software $\mathrm{R}$ version 3.2.3. to compare the respondents' answers from the different teaching areas and obtain a significant difference in correct answers' proportion.

The Committee of Ethics in Research from the State University of Maringá, Paraná State, Brazil, approved this study under protocol $\mathrm{n}^{0}$ 70690117.2.0000.0104. All participants signed a consent form and voluntarily accepted to participate in the research.

\section{Results}

A total of 600 students participated in the study, representing $7.5 \%$ of the graduate student population in daytime courses from the main campus in the city of Maringá (about 8,000 students). The students were between 16 and 40 years old (92.6\% were under 28 years old) and an average of 21.3 years old. This total, 514 had all questions evaluated, 80 replied that they had no knowledge about the subject and six left the questionnaire unanswered (Figure 1).

Considering the questionnaires answered by the 514 students, a total of 11,822 (100\%) questions were evaluated, and $5,215(44.1 \%)$ were correctly answered.

Figure 1. Study design of students' knowledge about toxoplasmosis in the aspects related to clinical features, prevention and routes of infections.

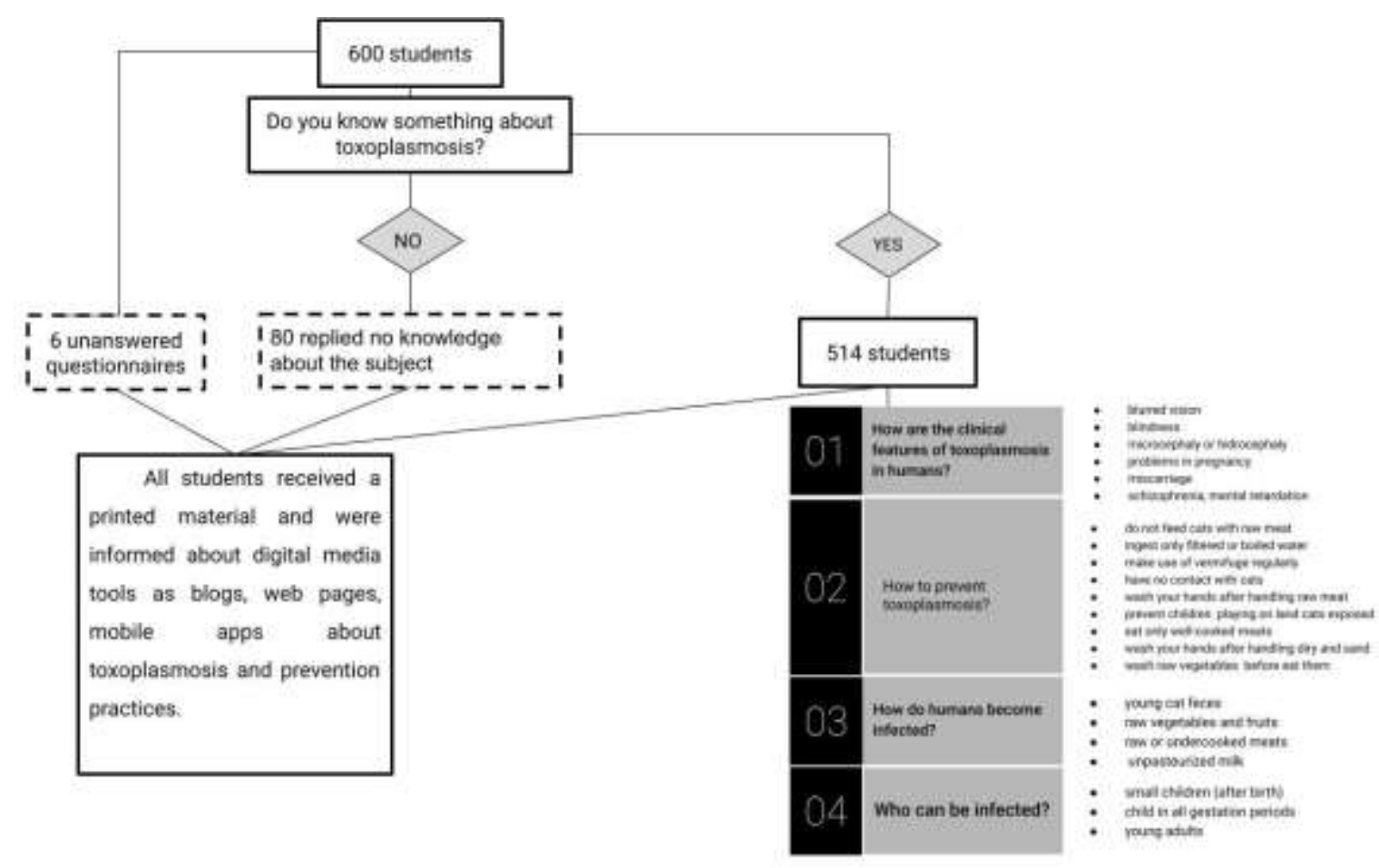

Source: Authors. 
The number of questionnaires answered by the 514 students from the four study areas and the proportions of hits per group are expressed in Figure 2.

Figure 2. Percentage of correct answers of different university student's groups according to study area.

\section{Percentage of correct answers}

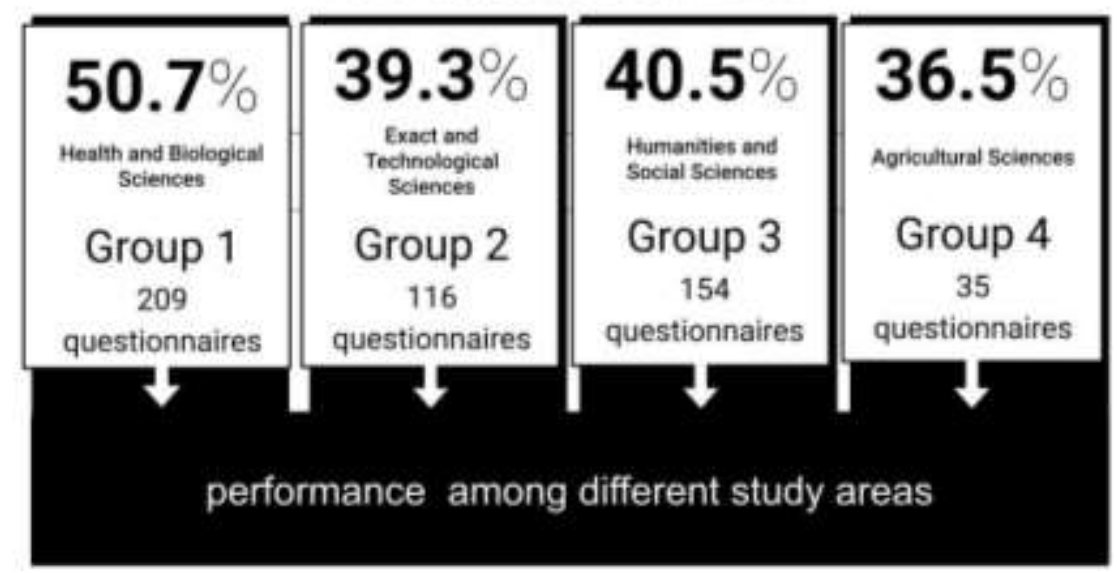

Source: Authors.

A substantial portion of students are not aware about transmission routes and prevention of this zoonosis. The lack of knowledge was observed about routes of transmissions and preventive practices (Figure 3). About clinical features, eye damage followed by problems with pregnancy were the main symptoms associated with T. gondii infection, but less than $20 \%$ knew other manifestations such as hydrocephalus or microcephaly, mental retardation and schizophrenia (Figure 3).

About preventive practices, statements such as "wash your hands after handling dirt and sand" and "prevent children from playing on land exposed to cats" were considered correct by $66.9 \%$ and $71.0 \%$ of the respondents respectively. In addition, 52,0\% correctly answered the statement "wash raw vegetables well before eating them". However, less than 50\% considered correct the options "do not feed cats with raw meat" (39.8\%), "eat only well-cooked meats" (40.1\%) and "ingest only filtered or boiled water" (42.6\%). Misconceptions about prevention and transmission routes were identified when statements such as "make use of vermifuge regularly" were considered correct by $20.0 \%$ of respondents (Figure 3 ). 
Figure 3. Percentage of correct answers from 514 respondents of students from the State University of Maringá (UEM), Paraná State, Southern Brazil in questions about toxoplasmosis transmission, sources of infection, prevention practices and manifestations.

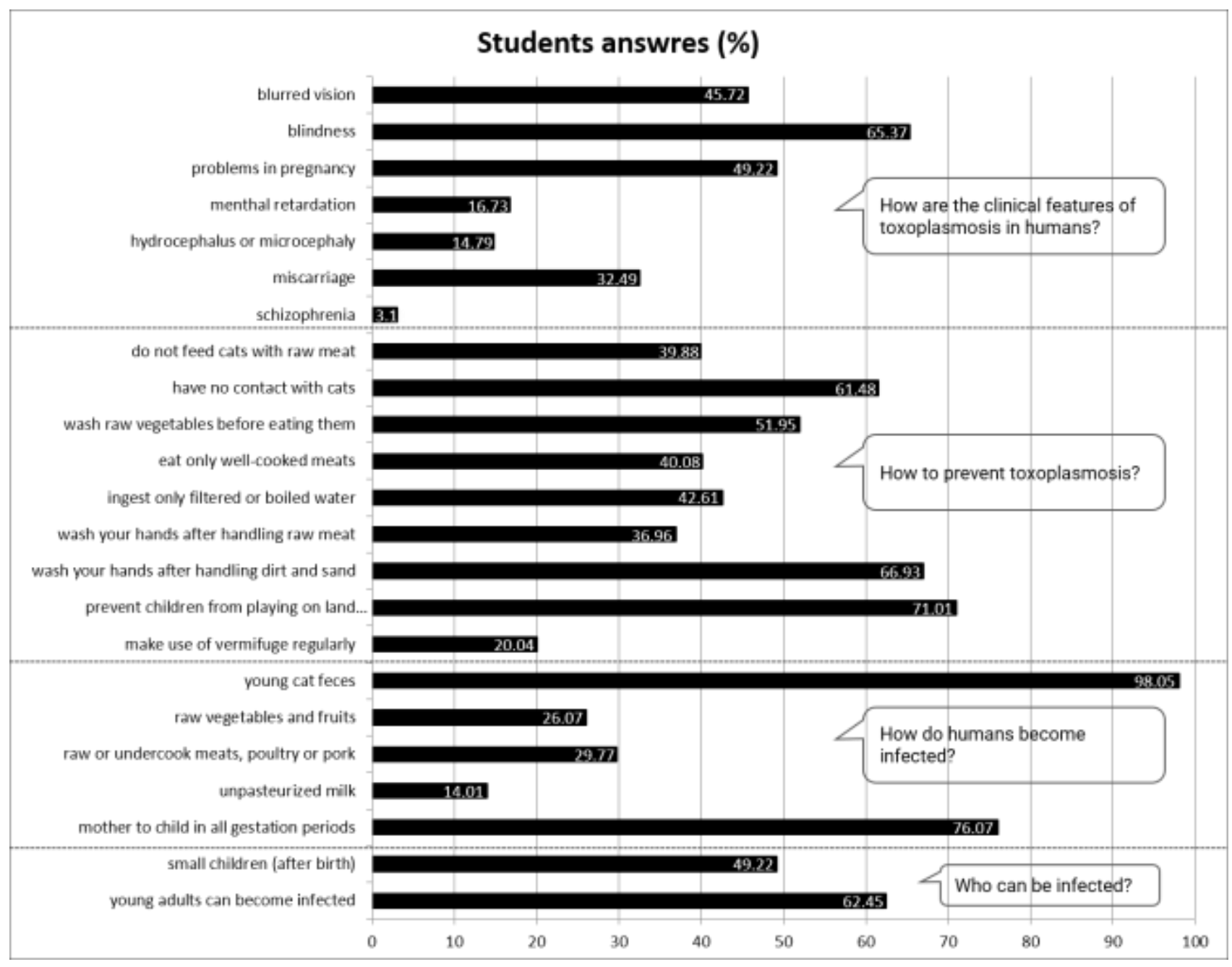

Source: Authors.

Table 1 shows performance comparison among the four study areas groups of the respondents. Group 1 (health and biological sciences) showed better results compared to the other groups $(\mathrm{p}<0.05)$. Observing the Odds Ratio between the groups, Group 1 (biological and health sciences) had 1,592 more chances to hit than group 2 (technological and exact sciences), and 1,514 more chances to hit than group 3 (humanities and social sciences). In addition, Group 1 had 44,2\% more chances of not getting wrong answers than group 4 (agricultural sciences). There were no statistical differences among the other groups comparisons (Table 1). 
Table 1. Comparison of correct answers in questions about toxoplasmosis among 514 young students respondents from different study areas of the State University of Maringá (UEM), Paraná State, Southern Brazil.

\begin{tabular}{|c|c|c|c|c|}
\hline Study areas groups & Estimates & $\begin{array}{l}\text { Standard } \\
\text { error }\end{array}$ & P-value & Odds Ratio \\
\hline G4 (Agric) X G1 (Biol/Health) & 0.5823 & 0.1177 & $<0.001$ & 0.558 \\
\hline G4 (Agric) X G2 (Exact/Tech) & 0.1172 & 0.1139 & 0.382 & 0.889 \\
\hline G4 (Agric) X G3 (Hum/Social) & 0.1675 & 0.1300 & 0.198 & 0.845 \\
\hline G1 (Biol/Health) X G2 (Exact/Tech) & -0.4650 & 0.0788 & $<0.001$ & 1.592 \\
\hline G1 (Biol/Health) X G3 (Hum/Social) & -0.4148 & 0.0720 & $<0.001$ & 1.514 \\
\hline G2 (Exact/Tech) X G3 (Hum/Social) & 0.0502 & 0.0842 & 0.551 & 0.950 \\
\hline
\end{tabular}

Group 1 - Biological and Health Sciences; Group 2 - Exact and Technological sciences; Group 3 - Humanities and Social Sciences; Group 4 - Agricultural Sciences. Source: Authors.

\section{Discussion}

This study is the first to evaluate university students' knowledge about toxoplasmosis in southern Brazil, a high prevalence region for toxoplasmosis (Lovison, 2017). The overall percentage of correct answers among students in this research was $44.1 \%$, which seems to be higher than other studies with different populations with less access to information, which was expected since the participants of this research are in undergraduate courses (Moura et al., 2017; Pereboom et al., 2013). They achieved a level of education that many cannot reach. A study carried out among homemakers demonstrates a shallow rate of knowledge $(<10 \%)$ if compared with our study (Velázquez-Hernández et al., 2019). Similarly, studies carried out among young female university students also show a low rate of knowledge (Al-Sheyab et al., 2015; Fitzmaurice et al., 2017; Senosy, 2020). However, despite more than 50\% of participants knowing about toxoplasmosis and correctly associated the disease with pregnancy problems, there is a lack of specific knowledge for adopting preventive practices. They know that toxoplasmosis is transmitted by contact with cat feces; otherwise, many participants still do not know the primary sources of transmission that makes toxoplasmosis a significant foodborne disease.

Participants in this study were young people and this age group represents the highest risk for T. gondii infection since seroprevalence of anti-T. gondii antibodies increase with age (Daryani et al., 2014; Dubey et al., 2012; Jones et al., 2001; Mareze et al., 2019). Also, most students live far from their family home which may contribute to eating habits that increase the exposure to transmission routes. Women in reproductive age draw special attention given the risk of congenital transmission of the infection to the fetus. Therefore, assessing the level of knowledge of this group of people is essential to guide preventive measures and health education.

For example, less than $52 \%$ of students considered washing raw vegetables well before eating, consuming wellcooked meats, and drinking filtered or boiled water as preventive practices to avoid $T$. gondii infection. It is possible to infer that the participants do not correlate the feline feces with water and vegetable contamination. Moreover, most students do not recognize that raw or undercooked meat is an essential source of contamination. This fact is worrying since toxoplasmosis is among the most critical diseases transmitted through water and food, according to the World Health Organization(World Health Organization, 2017). Indeed, ingestion of water and food contaminated with oocysts and tissue cysts in undercooked 
meat are the two main transmission routes of infection (Djurković-Djaković et al., 2019). A study conducted in the same geographical region of this research demonstrated the presence of $T$. gondii DNA in fresh leaves of vegetables sold in markets for human consumption (Marchioro et al., 2015). High-school students who had consumed undercooked meat had a 10.8 times greater risk of acquiring T. gondii infection, according to Galván-Ramírez (2010). Beyond that, two of the largest world's toxoplasmosis outbreaks were reported in the same region of this study, and there is evidence that water and vegetables are the main responsible for the source of infection in these outbreaks (Arquilla et al., 2019; Dubey, 2021; Pinto-Ferreira et al., 2020). Also, Yang et al (2017) demonstrated that gardening or agriculture and drinking untreated or unboiled water were risk factors to toxoplasmosis among young people in China, and most participants did not consider that rare meat could be a source of infection, regardless of the type of meat, whether beef, pork or poultry.

Most participants $(65.4 \%)$ correctly indicated blindness as a manifestation frequently associated with toxoplasmosis, but only $45,7 \%$ indicated other vision problems. In fact, retinochoroiditis is a common manifestation associated with high virulence of T. gondii diverse genotypes found in South America (Hamilton et al., 2019; Minuzzi et al., 2020). Although 76\% know about congenital transmission, important clinical features associated with gestational and congenital toxoplasmosis were ignored by a significant portion of respondents such as problems in pregnancy, hydrocephalus and microcephaly, cognitive and behavioral problems, and abortion. Lack of knowledge about acquiring the disease during pregnancy and about the severity of manifestations in the fetus can lead to under surveillance in care with environmental and food hygiene, enabling infection at this time, which will lead to the possibility of serious impacts to the fetus. Sanders et al (2017) observed that children congenitally infected during an outbreak of toxoplasmosis in Santa Isabel do Ivaí, Southern Brazil, after 5 years presented cognitive problems and school delay in addition to behavioral problems. Brazilian children congenitally infected had fivetimes higher risk of developing eye lesions than European children (Gilbert et al., 2008); and the lesions were frequently more severe and recurrent. In fact, even if $90 \%$ of the cases of postnatal T. gondii infection are asymptomatic, manifestations could range from low fever and mild lymphadenopathy to severe encephalitis, vision problems, psychiatric disorders, and cognitive deficit (Pearce et al., 2014; A. P. Sanders et al., 2017; Silva et al., 2008; Sugden et al., 2016).

The regular use of vermifuge was indicated as a preventive practice by $20.4 \%$ of the students. Despite being a relatively low percentage, this fact draws attention to the lack of knowledge that toxoplasmosis is a life time disease, and there is no effective treatment capable of eliminating the parasite from human organisms (Dunay et al., 2018; Peyron et al., 2019). Furthermore, the regular use of dewormers is a common practice which can bring a false sense of protection and lead to careless hygiene measures.

The average of correct answers by students in the health and biological areas was statistically higher than in other areas, while the agricultural area had the worst performance. It calls attention since the agricultural area is responsible for production of vegetables for human consumption, the important toxoplasmosis transmission route. Such difference could be attributed to the fact that the State University of Maringá has a group of studies and research about this zoonosis and the teaching hospital is a reference center in the outpatient clinic to attend gestational and congenital toxoplasmosis. For these reasons, the students of health and biological areas had more access to information than other areas, although still insufficient. Even among health professionals, insufficient knowledge about toxoplasmosis has been reported in several studies (AlvaradoEsquivel et al., 2011; da Silva et al., 2011; Efunshile et al., 2017). A survey conducted in health units, in the same geographic region of this study, showed that $83 \%$ of health professionals who attended pregnant women in prenatal care did not correctly answer what are the prophylactic measures to prevent $T$. gondii infection, but $100 \%$ stated that the presence of cats increases the risk of infection (Evangelista et al., 2017). People traditionally trust these professionals and they have an important role in providing information to patients, which reinforces the need for action and continued education programs on this zoonosis. 
This study did not measure whether there was an improvement in students' knowledge after health education actions. However, it is a fact that students in the health and biological areas had more access to information than the other areas, which may be a factor that contributed to their better performance in their responses. It has been shown that interventions in health education are effective to improve the knowledge about toxoplasmosis (Macre et al., 2019). Countries that have a congenital toxoplasmosis prevention program have a low prevalence of the disease, confirming the importance of preventing infection in pregnant women (Logar et al., 2002). The digital media effectiveness must also be considered since they allow more people to be reached, as user interaction through chat rooms and internet forums to answer questions and provide additional guidance (Dinesen et al., 2021; Evangelista et al, 2018; Hui D, 2021). Also, socioeconomic vulnerability determinants may be associated with T. gondii exposure and increase the risk of infection (Mareze et al., 2019).

\section{Conclusion}

Our study did not compare these results with the population outside the university, which could show greater lack of knowledge. It was also not possible to reach an equivalent sample between the different study areas analyzed. However, this research demonstrated the critical need to implement public policies to improve hygienic-sanitary conditions and permanent education programs for the population, as well as for health professionals, especially with regard to food safety. Toxoplasmosis is a preventable lifelong disease that presents severe manifestations and sequelae, especially in gestational and congenital infection, and there is no effective treatment available for the chronic phase. Therefore, correct preventive practices are the most important tool to control disease and reduce the prevalence of infections.

\section{Funding}

This work was carried out with the support of the Coordination for the Improvement of Higher Education Personnel Brazil (CAPES) for doctorate scholarship of the author Fernanda Ferreira Evangelista. - Financing Code 001.

\section{Acknowledgements}

We thank the students from the State University of Maringá who participated in the research.

\section{References}

Ait Hamou, S., \& Laboudi, M. (2021). An analytical study on the awareness and practice relating toxoplasmosis among pregnant women in Casablanca, Morocco. BMC Public Health, 21(1), 507. https://doi.org/10.1186/s12889-021-10474-9

Al-Sheyab, N. A., Obaidat, M. M., Bani Salman, A. e., \& Lafi, S. Q. (2015). Toxoplasmosis-Related Knowledge and Preventive Practices among Undergraduate Female Students in Jordan. Journal of Food Protection, 78(6), 1161-1166. https://doi.org/10.4315/0362-028X.JFP-14-579

Alvarado-Esquivel, C., Sifuentes-Álvarez, A., Estrada-Martínez, S., \& Rojas-Rivera, A. (2011). [Knowledge and practices on toxoplasmosis in physicians attending pregnant women in Durango, Mexico]. Gaceta Medica de Mexico, 147(4), 311-324. http://www.ncbi.nlm.nih.gov/pubmed/21894229

Arquilla, B., Bloem, C., Burguêz, D., Andrioli, G., \& Dal Ponte, S. T. (2019). Outbreak of Toxoplasmosis in the City of Santa Maria, Brazil. Journal of Infectious Diseases \& Preventive Medicine, 07(02). https://doi.org/10.35248/2329-8731.19.7.191

Bertran-Luengo, M. J., Jansà-Morató, M., Vidal-Flor, M., Núñez-Juárez, M., Isla-Pera, P., \& Escarrabill-Sanglas, J. (2021). Methodological guidelines for preparing a structured therapeutic education program: From design to evaluation. Revista Clínica Española (English Edition). https://doi.org/10.1016/j.rceng.2019.12.010

Bertranpetit, E., Jombart, T., Paradis, E., Pena, H., Dubey, J., Su, C., Mercier, A., Devillard, S., \& Ajzenberg, D. (2017). Phylogeography of Toxoplasma gondii points to a South American origin. Infection, Genetics and Evolution, 48, 150-155. https://doi.org/10.1016/j.meegid.2016.12.020

Binquet, C., Lejeune, C., Seror, V., Peyron, F., Bertaux, A.-C., Scemama, O., Quantin, C., Béjean, S., Stillwaggon, E., \& Wallon, M. (2019). The costeffectiveness of neonatal versus prenatal screening for congenital toxoplasmosis. PLOS ONE, 14(9), e0221709. https://doi.org/10.1371/journal.pone.0221709

Branco, B. H. M., de Araújo, S. M., \& Falavigna-Guilherme, A. L. (2012). Prevenção primária da toxoplasmose: Conhecimento e atitudes de profissionais de saúde e gestantes do serviço público de Maringá, estado do Paraná. Scientia Medica, 22(4), 185-190. 
Contiero-Toninato, A. P., Cavalli, H. O., Marchioro, A. A., Ferreira, É. C., Caniatti, M. C. da C. L., Breganó, R. M., Navarro, I., \& Falavigna-Guilherme, A. L. (2014). Toxoplasmosis: An examination of knowledge among health professionals and pregnant women in a municipality of the State of Paraná. Revista Da Sociedade Brasileira de Medicina Tropical, 47(2), 198-203. https://doi.org/10.1590/0037-8682-0016-2014

da Silva, L. B., de Oliveira, R. de V. C., da Silva, M. P., Bueno, W. F., Amendoeira, M. R. R., \& Neves, E. de S. (2011). Knowledge of Toxoplasmosis among Doctors and Nurses Who Provide Prenatal Care in an Endemic Region. Infectious Diseases in Obstetrics and Gynecology, 2011, 1-6. https://doi.org/10.1155/2011/750484

Dal Ponte, S., Burguez, D., \& Andrioli, G. (2019). Outbreak of Toxoplasmosis in the City of Santa Maria, Brazil. Prehospital and Disaster Medicine, 34(s1), s74-s74. https://doi.org/10.1017/S1049023X19001602

Daryani, A., Sarvi, S., Aarabi, M., Mizani, A., Ahmadpour, E., Shokri, A., Rahimi, M.-T., \& Sharif, M. (2014). Seroprevalence of Toxoplasma gondii in the Iranian general population: A systematic review and meta-analysis. Acta Tropica, 137, 185-194. https://doi.org/10.1016/j.actatropica.2014.05.015

de-la-Torre, A., López-Castillo, C. A., \& Gómez-Marín, J. E. (2009). Incidence and clinical characteristics in a Colombian cohort of ocular toxoplasmosis. Eye, 23(5), 1090-1093. https://doi.org/10.1038/eye.2008.219

Dinesen, B., Dam Gade, J., Skov Schacksen, C., Spindler, H., Eie Albertsen, A., Dittmann, L., Jochumsen, M., \& Svenstrup Møller, D. (2021). The Danish Future Patient Telerehabilitation Program for Patients With Atrial Fibrillation: Design and Pilot Study in Collaboration With Patients and Their Spouses. JMIR Cardio, 5(2), e27321. https://doi.org/10.2196/27321

Djurković-Djaković, O., Dupouy-Camet, J., Van der Giessen, J., \& Dubey, J. P. (2019). Toxoplasmosis: Overview from a One Health perspective. Food and Waterborne Parasitology, 15, e00054. https://doi.org/10.1016/j.fawpar.2019.e00054

Dubey, J. P. (2016). Toxoplasmosis of Animals and Humans. In Toxoplasmosis of Animals and Humans. CRC Press. https://doi.org/10.1201/9781420092370 Dubey, J. P., Lago, E. G., Gennari, S. M., Su, C., \& Jones, J. L. (2012). Toxoplasmosis in humans and animals in Brazil: high prevalence, high burden of disease, and epidemiology. In Parasitology. https://doi.org/10.1017/S0031182012000765

Dubey, J. P., Murata, F. H. A., Cerqueira-Cézar, C. K., Kwok, O. C. H., \& Villena, I. (2021). Congenital toxoplasmosis in humans: an update of worldwide rate of congenital infections. Parasitology, 1-11. https://doi.org/10.1017/S0031182021001013

Dubey, Jitender P. (2021). Outbreaks of clinical toxoplasmosis in humans: five decades of personal experience, perspectives and lessons learned. Parasites \& Vectors, 14(1), 263. https://doi.org/10.1186/s13071-021-04769-4

Dunay, I. R., Gajurel, K., Dhakal, R., Liesenfeld, O., \& Montoya, J. G. (2018). Treatment of Toxoplasmosis: Historical Perspective, Animal Models, and Current Clinical Practice. Clinical Microbiology Reviews, 31(4). https://doi.org/10.1128/CMR.00057-17

Efunshile, A. M., Elikwu, C. J., \& Jokelainen, P. (2017). Toxoplasmosis - Awareness and knowledge among medical doctors in Nigeria. PLOS ONE, 12(12), e0189709. https://doi.org/10.1371/journal.pone.0189709

Evangelista et al. (2018). Ferramentas online na prevenção da toxoplasmose. Revista Agape, 1(1).

Evangelista, F. F., Riedo, C. D. O., Andrade, A., \& Falavigna-guilherme, A. L. (2017). Análise do controle da toxoplasmose gestacional e ocular nos serviços de Atenção Primária da 15ª Regional de Saúde do Paraná. REVISTA DE SAÚDE PÚBLICA DO PARANÁ, 18(1), 39-44.

Fallahi, S., Rostami, A., Nourollahpour Shiadeh, M., Behniafar, H., \& Paktinat, S. (2018). An updated literature review on maternal-fetal and reproductive disorders of Toxoplasma gondii infection. Journal of Gynecology Obstetrics and Human Reproduction, 47(3), 133-140. https://doi.org/10.1016/j.jogoh.2017.12.003

Fitzmaurice, C., Allen, C., Barber, R. M., Barregard, L., Bhutta, Z. A., Brenner, H., Dicker, D. J., Chimed-Orchir, O., Dandona, R., Dandona, L., Fleming, T., Forouzanfar, M. H., Hancock, J., Hay, R. J., Hunter-Merrill, R., Huynh, C., Hosgood, H. D., Johnson, C. O., Jonas, J. B., ... Naghavi, M. (2017). Global, Regional, and National Cancer Incidence, Mortality, Years of Life Lost, Years Lived With Disability, and Disability-Adjusted Life-years for 32 Cancer Groups, 1990 to 2015. JAMA Oncology, 3(4), 524. https://doi.org/10.1001/jamaoncol.2016.5688

Galván-Ramírez, ML; Pérez, LRR; Agraz SYL; Ávila, LMS; RuÍz, ASA; Corella, DB; Fernández, BJRF; Sanromán, R. (2010). Seroepidemiology of toxoplasmosis in high-school students in the metropolitan area of Guadalajara, Jalisco, Mexico. Scientia Medica, $20,59-63$. http://revistaseletronicas.pucrs.br/ojs/index.php/scientiamedica/article/viewArticle/5639

Gilbert, R. E., Freeman, K., Lago, E. G., Bahia-Oliveira, L. M. G., Tan, H. K., Wallon, M., Buffolano, W., Stanford, M. R., \& Petersen, E. (2008). Ocular Sequelae of Congenital Toxoplasmosis in Brazil Compared with Europe. PLoS Neglected Tropical Diseases, $2(8)$, e277. https://doi.org/10.1371/journal.pntd.0000277

Hamilton, C. M., Black, L., Oliveira, S., Burrells, A., Bartley, P. M., Melo, R. P. B., Chianini, F., Palarea-Albaladejo, J., Innes, E. A., Kelly, P. J., \& Katzer, F. (2019). Comparative virulence of Caribbean, Brazilian and European isolates of Toxoplasma gondii. Parasites and Vectors. https://doi.org/10.1186/s13071$019-3372-4$

Higa, L. T., Araújo, S. M., Tsuneto, L., Castilho-Pelloso, M., Garcia, J. L., Santana, R. G., \& Falavigna-Guilherme, A. L. (2010). A prospective study of Toxoplasma-positive pregnant women in southern Brazil: a health alert. Transactions of the Royal Society of Tropical Medicine and Hygiene, 104(6), 400405. https://doi.org/10.1016/j.trstmh.2010.01.006

Hui D, M.-U. M. (2021). Workplace Electronic Health Promotion Campaigns for Tobacco Smoking Prevention or Cessation. Canadian Agency for Drugs and Technologies in Health.

Jones, J. L., Parise, M. E., \& Fiore, A. E. (2014). Neglected Parasitic Infections in the United States: Toxoplasmosis. The American Journal of Tropical 
Medicine and Hygiene, 90(5), 794-799. https://doi.org/10.4269/ajtmh.13-0722

Jones J et al., 2001. (2001). Toxoplasma gondii Infection in the United States: Seroprevalence and Risk Factors. American Journal of Epidemiology, 154(4), 357-365. https://doi.org/10.1093/aje/154.4.357

Khan, A. (2006). Genetic Divergence of Toxoplasma gondii Strains Associated with Ocular Toxoplasmosis, Brazil. Emerging Infectious Diseases, 12(6), 942949. https://doi.org/10.3201/eid1206.060025

Logar, J., Petrovec, M., Novak-Antolic, Z., Premru-Srsen, T., Cizman, M., Arnez, M., \& Kraut, A. (2002). Prevention of Congenital Toxoplasmosis in Slovenia by Serological Screening of Pregnant Women. Scandinavian Journal of Infectious Diseases, 34(3), 201-204. https://doi.org/10.1080/00365540110080386

Lovison, R. R. M. R. (2017). Incidência E Prevalência Da Toxoplasmose Na Região Sul Do Brasil : Revisão Bibliográfica. Rev. Saúde Públ. Santa Cat, 10(3), 61-75. http://revista.saude.sc.gov.br/index.php/inicio/article/view/584/403

Macre, M. de S., Meireles, L. R., Sampaio, B. F. C., \& Andrade Júnior, H. F. de. (2019). Saliva collection and detection of anti- T. gondii antibodies of lowincome school-age children as a learning strategy on hygiene, prevention and transmission of toxoplasmosis. Revista Do Instituto de Medicina Tropical de São Paulo, 61. https://doi.org/10.1590/s1678-9946201961048

Maldonado, Y. A., Nizet, V., Klein, J. O., Remington, J. S., \& Wilson, C. B. (2011). Current Concepts of Infections of the Fetus and Newborn Infant. In Infectious Diseases of the Fetus and Newborn (pp. 2-23). Elsevier. https://doi.org/10.1016/B978-1-4160-6400-8.00001-8

Marchioro, A. A., Colli, C. M., Ferreira, C., Viol, B. M., Araújo, S. M., \& Falavigna-Guilherme, A. L. (2015). Risk factors associated with toxoplasmosis and toxocariasis in populations of children from nine cities in southern Brazil. Journal of Helminthology. https://doi.org/10.1017/S0022149X14000212

Mareze, M., Benitez, A. do N., Brandão, A. P. D., Pinto-Ferreira, F., Miura, A. C., Martins, F. D. C., Caldart, E. T., Biondo, A. W., Freire, R. L., MitsukaBreganó, R., \& Navarro, I. T. (2019). Socioeconomic vulnerability associated to Toxoplasma gondii exposure in southern Brazil. PLOS ONE, 14(2), e0212375. https://doi.org/10.1371/journal.pone.0212375

Martini, A., Pietrafesa, E., Rondinone, B. M., Iavicoli, S., D’amelio, S., Cavallero, S., \& Bonafede, M. (2020). Toxoplasmosis and knowledge: what do the Italian women know about? Epidemiology and Infection, 148, e256. https://doi.org/10.1017/S0950268820002393

Minuzzi, C. E., Portella, L. P., Bräunig, P., Sangioni, L. A., Ludwig, A., Ramos, L. S., Pacheco, L., Silva, C. R., Pacheco, F. C., Menegolla, I. A., Farinha, L. B., Kist, P. P., Breganó, R. M., Nino, B. de S. L., Cardoso Martins, F. D., Monica, T. C., Ferreira, F. P., Britto, I., Signori, A., ... Flores Vogel, F. S. (2020). Isolation and molecular characterization of Toxoplasma gondii from placental tissues of pregnant women who received toxoplasmosis treatment during an outbreak in southern Brazil. PLOS ONE, 15(1), e0228442. https://doi.org/10.1371/journal.pone.0228442

Montoya, J., \& Liesenfeld, O. (2004). Toxoplasmosis. The Lancet, 363(9425), 1965-1976. https://doi.org/10.1016/S0140-6736(04)16412-X

Moura, L. P. e, Oliveira, J. M. de, Noronha, D. D., Torres, J. D. R. V., Oliveira, K. C. F., \& Teles, M. A. B. (2017). Percepção de mães cadastradas em uma estratégia saúde da família sobre aleitamento materno exclusivo. Journal of Nursing UFPE on Line .

Pearce, B. D., Kruszon-Moran, D., \& Jones, J. L. (2014). The association of Toxoplasma gondii infection with neurocognitive deficits in a population-based analysis. Social Psychiatry and Psychiatric Epidemiology, 49(6), 1001-1010. https://doi.org/10.1007/s00127-014-0820-5

Pena, H. F. J., Alves, B. F., Soares, H. S., Oliveira, S., Ferreira, M. N., Bricarello, P. A., Machado, T. M. P., Castro, B. B. P., \& Gennari, S. M. (2018). Freerange chickens from Santa Catarina state, southern Brazil, as asymptomatic intermediate hosts for Toxoplasma gondii clonal type I and typical Brazilian genotypes. Veterinary Parasitology: Regional Studies and Reports, 13, 55-59. https://doi.org/10.1016/j.vprsr.2018.04.001

Pereboom, M. T. R., Manniën, J., Spelten, E. R., Schellevis, F. G., \& Hutton, E. K. (2013). Observational study to assess pregnant women's knowledge and behaviour to prevent toxoplasmosis, listeriosis and cytomegalovirus. BMC Pregnancy and Childbirth, 13(1), 98. https://doi.org/10.1186/1471-2393-13-98

Peyron, F., L’ollivier, C., Mandelbrot, L., Wallon, M., Piarroux, R., Kieffer, F., Hadjadj, E., Paris, L., \& Garcia -Meric, P. (2019). Maternal and Congenital Toxoplasmosis: Diagnosis and Treatment Recommendations of a French Multidisciplinary Working Group. Pathogens, 8(1), 24. https://doi.org/10.3390/pathogens 8010024

Pinto-Ferreira, F., Nino, B. de S. L., Martins, F. D. C., Monica, T. C., Britto, I. C., Signori, A., Medici, K. C., Freire, R. L., Navarro, I. T., Garcia, J. L., Headley, S. A., Vogel, F. S. F., Minuzzi, C. E., Portella, L. P., Bräunig, P., Sangioni, L. A., Ludwig, A., Ramos, L. S., Pacheco, L., ... Mitsuka-Breganó, R. (2020). Isolation, genetic and immunohistochemical identification of Toxoplasma gondii from human placenta in a large toxoplasmosis outbreak in southern Brazil, 2018. Infection, Genetics and Evolution, 85, 104589. https://doi.org/10.1016/j.meegid.2020.104589

Robert-Gangneux, F., Dardé, M. L., Darde, M.-L. M., Wang, M., Chen, J., Huang, S. S.-Y., Gao, Q., Zhu, X. X.-Q., Robert-Gangneux, F., Darde, M.-L. M., Cenci-Goga, B., Rossitto, P., Sechi, P., McCrindle, C., Cullor, J., Dubey, J., Zhou, P., Chen, Z., Li, H. H., ... Verschueren, H. (2012). Epidemiology of and diagnostic strategies for toxoplasmosis. Clinical Microbiology Reviews, 25(2), 264-296. https://doi.org/10.1128/CMR.05013-11

Rudzinski, M., Argüelles, C., Couto, C., Oubiña, J. R., \& Reina, S. (2019). Immune Mediators against Toxoplasma Gondii during Reactivation of Toxoplasmic Retinochoroiditis. Ocular Immunology and Inflammation, 27(6), 949-957. https://doi.org/10.1080/09273948.2018.1499940

Rudzinski, M., Khoury, M., Couto, C., \& Ajzenberg, D. (2016). Reactivation of Ocular Toxoplasmosis in Non-Hispanic Persons, Misiones Province, Argentina. Emerging Infectious Diseases, 22(5), 912-913. https://doi.org/10.3201/eid2205.150025

Sanders, A. P., dos Santos, T., Felipe, C. K. K., Estevão, M. L., Cícero, C., Evangelista, F., Manrique, C. A., Mizutani, A. S., \& Falavigna-Guilherme, A. L. (2017). Ocular Lesions in Congenital Toxoplasmosis in Santa Isabel do Ivaí, Paraná, Brazil. Pediatric Infectious Disease Journal, 36(9), 817-820. https://doi.org/10.1097/INF.0000000000001614 
Sanders, J. L., Zhou, Y., Moulton, H. M., Moulton, Z. X., McLeod, R., Dubey, J. P., Weiss, L. M., \& Kent, M. L. (2015). The zebrafish, Danio rerio, as a model for Toxoplasma gondii : an initial description of infection in fish. Journal of Fish Diseases, 38(7), 675-679. https://doi.org/10.1111/jfd.12393

Senosy, S. A. (2020). Knowledge and attitudes about toxoplasmosis among female university students in Egypt. International Journal of Adolescent Medicine and Health. https://doi.org/10.1515/ijamh-2019-0207

Silva, C. S. P., Neves, E. de S., Benchimol, E. I., \& Moraes, D. R. de. (2008). Postnatal acquired toxoplasmosis patients in an infectious diseases reference center. Brazilian Journal of Infectious Diseases, 12(5). https://doi.org/10.1590/S1413-86702008000500016

Silveira, C., Muccioli, C., Holland, G. N., Jones, J. L., Yu, F., De Paulo, A., \& Belfort, R. (2015). Ocular involvement following an epidemic of toxoplasma gondii infection in santa isabel do ivaí, Brazil. American Journal of Ophthalmology, 159(6), 1013-1021.e3. https://doi.org/10.1016/j.ajo.2015.02.017

Smith, N. C., Goulart, C., Hayward, J. A., Kupz, A., Miller, C. M., \& van Dooren, G. G. (2021). Control of human toxoplasmosis. International Journal for Parasitology, 51(2-3), 95-121. https://doi.org/10.1016/j.ijpara.2020.11.001

Sugden, K., Moffitt, T. E., Pinto, L., Poulton, R., Williams, B. S., \& Caspi, A. (2016). Is Toxoplasma Gondii Infection Related to Brain and Behavior Impairments in Humans? Evidence from a Population-Representative Birth Cohort. PloS One, 11(2), e0148435. https://doi.org/10.1371/journal.pone.0148435

Velázquez-Hernández, N., Avilés Ávila, A. Y., Rivas-González, M. A., Delgado-González, S. P., Alvarado-Félix, G. A., Alvarado-Félix, Á. O., BeristainGarcia, I., \& Alvarado-Esquivel, C. (2019). Knowledge and practices regarding toxoplasmosis in housewives: A cross sectional study in a northern Mexican city. PLOS ONE, 14(9), e0222094. https://doi.org/10.1371/journal.pone.0222094

Waldman, B. S., Schwarz, D., Wadsworth, M. H., Saeij, J. P., Shalek, A. K., \& Lourido, S. (2020). Identification of a Master Regulator of Differentiation in Toxoplasma. Cell, 180(2), 359-372.e16. https://doi.org/10.1016/j.cell.2019.12.013

World Health Organization. (2017). The Burden of Foodborne Diseases in the WHO European Region. World Health Organization, 1-48. http://www.euro.who.int/en/health-topics/disease-prevention/food-safety/publications/2017/the-burden-of-foodborne-diseases-in-the-who-european-region2017

Yang, N., Wang, D., Xing, M., Li, C., Li, J., Wu, A., Sang, X., Feng, Y., Jiang, N., \& Chen, Q. (2017). Seroepidemiology and Risk Factors of Toxoplasma gondii Infection among the Newly Enrolled Undergraduates and Postgraduate Students in China. Frontiers in Microbiology, 8. https://doi.org/10.3389/fmicb.2017.02092

Yang, Y., Yu, S.-M., Chen, K., Hide, G., Lun, Z.-R., \& Lai, D.-H. (2020). Temperature is a key factor influencing the invasion and proliferation of Toxoplasma gondii in fish cells. Experimental Parasitology, 217, 107966. https://doi.org/10.1016/j.exppara.2020.107966

Yoshida, N., Domart, M.-C., Peddie, C. J., Yakimovich, A., Mazon-Moya, M. J., Hawkins, T. A., Collinson, L., Mercer, J., Frickel, E.-M., \& Mostowy, S. (2020). The zebrafish as a novel model for the in vivo study of Toxoplasma gondii replication and interaction with macrophages. Disease Models \& Mechanisms, 13(7). https://doi.org/10.1242/dmm.043091 